\title{
Judicial Control of the Administration in the Republic of Kosovo
}

\author{
Hysni Bajrami \\ European University of Tirana, Faculty of Law, Public Administration \\ hysnibajrami@yahoo.com
}

\section{Doi:10.5901/ajis.2015.v4n1s1p85}

\section{Abstract}

In all countries with developed democracy, the control of the work of the administration by the courts is an acceptable and applicable principle in the best European practices and wider. The building of a modern, professional and efficient administration is the goal of every country that is aspire the integration to the European Union. The development of the public administration and the reforms in this sector aims to bring closer the public administration with the citizen and offering more effective and quality services. But all this important and wide variety of activities offered by the administration cannot remain uncontrolled, because the lack of control may result in violations and abuse of the rights of citizens. In this aspect the judicial control is considered as the most effective mean to protect the individual rights of the citizens from eventual violations and abuse by the administration. The Republic of Kosovo has made some important steps in this direction. The adoption of the new Law on Courts and the recent amendments to this Law, present the clear steps which have been undertaken with the purpose of improving the performance of the judiciary. The establishment of a special department within the Basic Court of Pristina, is expected to efficiently and effectively impact the hearing of the administrative cases, and at the same time it will have an impact on improving the work of the administration. The administration needs to be aware that there will be a substantial control over the legality of the acts such administration passes.

Keywords: Administration, legality, court, control, judicial.

\section{Introduction}

In all countries with developed democracy, the control of the work of the administration by the courts is an acceptable and applicable principle in the best European practices and wider. The building of a modern, professional and efficient administration is the goal of every country that is aspire the integration to the European Union. The development of the public administration and the reforms in this sector aims to bring closer the public administration with the citizen and offering more effective and quality services.

But all this important and wide variety of activities offered by the administration cannot remain uncontrolled, because the lack of control may result in violations and abuse of the rights of citizens. In this aspect the judicial control is considered as the most effective mean to protect the individual rights of the citizens from eventual violations and abuse by the administration.

The Republic of Kosovo has made some important steps in this direction. The adoption of the new Law on Courts ${ }^{1}$ and the recent amendments to this Law, present the clear steps which have been undertaken with the purpose of improving the performance of the judiciary.

The establishment of a special department within the Basic Court of Pristina, is expected to efficiently and effectively impact the hearing of the administrative cases, and at the same time it will have an impact on improving the work of the administration. The administration needs to be aware that there will be a substantial control over the legality of the acts such administration passes.

1 Law on Courts, Nr. 03L - 199, as amended with Decree of the President of the Republic of Kosovo. DL-047-2010, Date 09.08.2010 (Official newspaper of the Republic of Kosovo / Pristina: Since V/ no. 79/24 August 2010). 


\section{Development}

\subsection{The Overall review of the work of the administration and control}

The public administration represents an important sector within the country. The average workload of its sectors commitments is significantly large. The control of the work of administration is considered to be means of prevention or elimination of intentional or unintentional mistakes of administration employees.

The control of the work of administration is performed in two different ways: 1. the internal control and 2. the external control.

The internal control is conducted by the higher bodies of the administration. In the contemporary administrative systems there are two types of internal control of the work of administration: a) the institutional control, as a rule is accomplished based on a dissatisfaction expressed by a party, namely, according to the appeal. Through the appeal the concrete lower administrative body act is ahead the highest administrative body. b) The hierarchical control, is the form of control realized on the hierarchical authority, and hence the higher authorities not only have the right to supervise the work of lower bodies but they have an obligation to perform it. This type of control is committed through the inspection and audit.

The external control is conducted by specialized bodies that have the competence and the right to operate in this field. This type of control is committed by several bodies, among them may be, the parliament, the ombudsperson and the courts. Among the most important forms, what in theoretical aspect is also considered to be the most controversial form of work control of the administration, is the judicial control, consequently this is going to be the key part of this analysis.

\subsection{The judicial review of the administrative actions}

The judicial control of the administration, implies the authority that is given to the political and administration independent body, to resolve conflicts that have been incurred by the functioning of the administration ${ }^{2}$. The conflict in the administrative field arises when a party alleges that through a particular administrative act subjective rights have been violated, respectively there were legal violations. In this regard the institution of judicial control is presented as a constitutional guarantee for the protection of the freedoms and human rights through the fair and public trial from independent ${ }^{3}$ court.

\subsection{Forms of the judicial control}

Courts during the inspection of the work of administration, actually do the control of the legality of administrative acts, which control is performed or accomplished in two main forms:

1. The general control, accomplished through administrative conflict procedure and

2. The judicial protection of human rights, conducted by the Constitutional Court, when it is determined that the specific administrative act violated human rights.

Typical form of administrative judiciary is an administrative dispute (conflict).

\subsection{Administrative conflicts}

The aim of administrative conflict is provision of judicial protection of rights and interests for legal and natural persons and other parties, the rights and interests that have been violated by individual decisions or by actions of public administrative authorities, as well as the protection of lawfulness.

The issue of administrative conflict in the Republic of Kosovo is regulated by the Law on administrative conflict 4 .

With this law are regulated competencies and composition of the court as well as the rules of procedure, based on which the competent courts shall decide on lawfulness of administrative acts by which the competent authorities of public

\footnotetext{
2 Esat Stavileci, "Hyrje në shkencat administrative", Prishtina, 1997, p.129.

3 Sokol Sadushi, "E drejta Administrative", Tirana, 2008, p.266.

4 Law No.03/L-202 Administrative Conflict, 16 September, 2010 
administration shall decide on rights, obligations and legal interests of legal and natural persons, and other parties, as well as for the lawfulness of actions of administrative authorities ${ }^{5}$

Based on a law, an administrative conflict can start only against the administrative act issued in the administrative procedure of the court of appeals, but in some cases an administrative conflict procedure can also start against the administrative act of the first instance, against which in the administrative procedure, complain is not allowed ${ }^{6}$. But there is another situation where a party can open an administrative procedure that occurs in the case of inaction of the administrative body, even after the appeal in second instance. Therefore, the party who is dissatisfied with the decision of the first instance authority, carries the right to appeal within the legal deadline ${ }^{7}$, but the body does not issue a decision on the appeal ${ }^{8}$, what then arises the right to address the court?

Administrative Conflict begins with the claim. The plaintiff of administrative conflict may be a natural person, legal person, the ombudsperson, the associations and other organizations, that act for protection of the public interest, who considers that the administrative act has violated directly or indirectly any right or interest, based on the law.

\subsection{The judgment of administrative acts by the Constitutional Court}

In the theory of law it is considered a very controversial issue, the ratio of the constitutional court with the regular courts, that adjudicate administrative issues, therefore which acts are the subject of which court. Clarifying the above mentioned division of control, it should be said, that there is an agreement that the acts of general character (normative) should not be subject of the regular courts interpretation, but that competence should be left to the Constitutional Court.

In this regard only the acts of individual character can be treated in administrative judiciary contexts, and they may be the subject to regular courts ${ }^{10}$. This attitude, in a way is the matter of the law on administrative conflict, wherein in article 15, paragraph 3, states: "Administrative conflict cannot be developed against administrative acts that constitute a general obligation issued by administrative authorities, unless they violate legitimate rights of the parties". Constitutional Court of the Republic of Kosovo, in many cases has decided on institutions decisions, by which decisions the rights and freedoms of citizens have been violated, as defined in the constitution. Only in 2011 there were 18 cases or 10.98\% of the requests to the court, referring to the decisions of government institutions ${ }^{11}$. The decisions that allegedly violated human rights and freedoms are guaranteed by the Constitution.

\section{Judicial Administration Control Systems}

There are mainly two administrative judiciary systems in the word, the French system and the Anglo-Saxon system. The French system envisions the creation of specific administrative courts that will have the competence of judgment on administrative issues, exclusively. Whereas Anglo-Saxon system foresees that administrative issues should be resolved within the regular courts.

This system is a characteristic of Anglo-Saxon countries (common law), but it is also implemented in other countries. According to this system the public administration activities are subject to the ordinary jurisdiction trial.

In theory, there are various discussions about the factors that influence the country to choose the specified type of judiciary administrative acts control. At present, in sixteen ${ }^{12}$ European Union countries particular administrative court exists. Whereas in eleven ${ }^{13}$ other countries, administrative rights are being operating by specialized subsidiaries, within the framework of regular courts, commonly within the Supreme Court.

\footnotetext{
5 Ibidem, article 1.

6 Ibidem, article 13

7 Legal deadline for appeal in second instance is 30 days. Article 131, Law no. 02 / L-28 on Administrative Procedure

8 In theory this is known as "administrative silence"

${ }_{9}$ The current law on administrative proceedings, refers incorrectly to civil proceedings rather than the law onadministrative conflict, probably this will be changed by this law amendement.

10 For more information read, Sokol Sadushi, "Kontrolli Kushtetues", Tirana, 2004, p. 96

11 Constitutional Court of the Republic of Kosovo, Annual Report, 2011, http://www.gjk-ks.org/repository/docs/Raporti\%20Vjetor\%202011\%20Versioni\%20Finalpdf.

12 Germany, Austria, Belgium, Finland, France, Greece, Italy, Latvia, Luxembourg, Netherlands, Poland, Portugal, Czech Republic, Sweden, Romania and Bulgaria.

${ }^{13}$ Cyprus, Estonia, Denmark, Ireland, Lithuania, Hungary, Malta, Spain, Slovenia, Slovakia and the UK 
The great importance given to administrative judiciary within the European Union, has influenced various debates, to talk about what is already called the "Europeanisation" of the administrative judiciary. 'Europeanisation' implies the standards within the EU, as regard the field ${ }^{14}$.

Kosovo has selected to meet the Anglo-Saxon system of administrative judiciary, where the administrative litigation are resolved within the regular courts. Until January the $1^{\text {st }}$ of 2013 the Supreme Court was responsible of judgment on administrative matters, respectively the special room for administrative disputes, which operated besides it ${ }^{15}$.

After the reforms and after the new law for the courts has come into force, administrative issues are within the exclusive competence of the Court in Pristina ${ }^{16}$.

\section{The Functioning of the Administrative Judiciary in Kosovo}

Since the end of the war the Republic of Kosovo has been the target of criticism from both local and international stakeholders. Numerous international reports ${ }^{17}$ have revealed major deficiencies in functioning, ascertaining major violations of human rights and freedoms in many judicial proceedings.

The judicial protection of the rights of citizens guaranteed by the Constitution of the Republic of Kosovo18, the Law on Courts ${ }^{19}$, and the European Convention for the Protection of Fundamental Human Rights and Freedoms with its Protocols being directly applied in Republic of $\mathrm{KoSOVO}^{20}$, continues to be accompanied by the numerous challenges. Despite the efforts, many promises and declarations of progress in this field, due to poor conditions in the judicial system in the country ${ }^{21}$, great difficulties in realizing of this right has been faced.

Since January of current year, the Law on Courts ${ }^{22}$, came into force in its general form, through which the judicial system in Kosovo has conducted the reform. Will these reforms prove success, it remains to be seen in the future, for it is still early to make judgment, as only few months have passed since the judicial system has started to function based on the new law.

\section{The Judgment of the Administrative Issues}

Kosovo is at a very important stage of the reforms on public administration, with the intention to establish an administration that functions according to the European parameters and which is able to provide efficient services to all, services that are based on the law and with no violation of them.

On ensuring that the administrative acts issued by public administration are in accordance with the law, the process of judicial control is considered. As regards the above mentioned judicial reforms, besides other changes, it has also brought changes in judgment of administrative issues. Currently, in this course, the judgment of administrative conflict issues, is the exclusive competence of the Court in Pristina ${ }^{23}$.

This court is the only one in Kosovo that is going to have the Department for Administrative Affairs. In this

14 Esat Stavileci,"Gjyqësia administrative, mundësit dhe përparësitë", Paper presented at the conference organized by the University "Marin Barleti" në Tiran, on 4.02. 2011

${ }^{15}$ Article 31.5 Law on Regular Courts, Official Gazette of SFRJ, no. 21, April 28, 1978.

${ }^{16}$ Article 11.3 Law No.03 / L-199 on Courts, July 22, 2010

${ }_{17}$ European Commission, "Communication from the Commission to the Feasibility Study for a Stabilisation and Association Agreement between the European Union and Kosovo", Brussels, 10.10.2012. http://ëëë.meiks.net/repository/docs/Dokumenti_punues_i_Komisionit Evropian_mbi_SF_per_MSA_mes_BE-se_dhe_Kosoves.pdf.

18 The Constitution of the Republic of Kosovo, Article 54: "Everyone enjoys the right of judicial protection if any right guaranteed by this Constitution or by law has been violated or denied and has the right to an effective legal remedy if found that such right has been violated".

${ }^{19}$ Law on Courts, no. 03L-199, Article 7. p. 3 (Official newspaper of the Republic of Kosovo / Pristina: Year V / no. 79/24 August 2010):

"Every person has the right to address the courts to protect and enforce his or her legal rights. Everyperson has the right to pursue legal remedies against judicial and administrative decisions that infringe on his or her rights or interests, in the manner provided by Law"

20 The Constitution of the Republic of Kosovo, Article 22, $p$ (2) European Convention on the Protection of Human Rights and Fundamental Freedoms and its Protocols.

21 The Ombudsman of the Republic of Kosovo, Annual Report, 2011, pp 98-105.http://www.ombudspersonkosovo.org/repository/ docs/91976_RAPORTI\%202011\%20shqip.pdf.

22 Law on Courts, no. 03L-199, Article 7. p. 3 (Official newspaper of the Republic of Kosovo / Pristina: Year V / no. 79/24 August 2010).

23 Law No. 03 / L-199 on Courts, Article 11. 
department, the law provides that the administrative issues are judged by a professional judge. If the party is not satisfied with the decision taken in the framework of the Basic Court, then the Court of Appeal can be addressed, which has jurisdiction to review all appeals against the decisions of the Basic Court ${ }^{24}$. In the Court of Appeal issues are judged by three professional judges ${ }^{25}$.

The Department of Administrative Affairs in the Basic Court in Pristina, consists of three judges that adjudicate cases of administrative dispute. Commitment in this department, regarding the review of lawsuits has started on 28 of March ${ }^{26}$. Since January the $1^{\text {st }}$, when judicial reform in this department has started, cases from Supreme Court have been received, this procedure lasted until March 25th. During this time 1,800 cases in total, have been received. So far, the department has not released any judgment ${ }^{27}$. Not issuing any judgment, leaves no reason of justifying the commitment of the department, although the judges of the Basic Judge, associate the delay with the reform process. They say that the transfer of cases from the Supreme Court has created difficulties in this regard.

The greatest problem in this department remains small number of judges, there are three judges at the present time, what is considered to be very small number, regarding the large number of cases that were transferred from the Supreme Court.

\section{The Necessity of Establishing the Administrative Court in Kosovo}

Current approaches of administrative issues settlement, that are conducted by regular courts of Kosovo makes it to be the part of the Anglo-Saxon system, where special administrative courts exists.

Due to the need of the time and the processes through which are passing, most countries in the region have established these courts. Building the rule of law, first of all, is based on the protection of human rights and freedoms, which protection can best be accomplished by issuing legal decisions that affect individual interests. Therefore, in this respect Kosovo should review the possibility of establishing a specialized court for administrative matters ${ }^{28}$.

It should be stated that Kosovo, in terms of legislation, is close to the European Union ones, meanwhile it still has not passed the challenges that the region countries have faced in terms of harmonization of legislation with EU standards, thus this could be an advantage towards establishing an administrative court.

Reform which has occurred by the new law for the courts, seems that have been overshadowed, as well as it has not adequately addressed the issue of administrative judiciary. Changes on the law on administrative procedure, should have been a priority in this regard.

The academic Esat Stavileci while analyzing the advantages of establishing an administrative court, highlights three main aspects:

Firstly, in the effort to build the rule of law, the role of administrative judiciary is of particular importance, in terms of strengthening the protection of rights and interests of citizens.

Secondly, in the efforts to institutionalize legal protection in general, the administrative judiciary could be regarded a powerful impact on protection and safety of objective lawfulness, that in the past was violated and continues to be breached even nowadays.

Thirdly, in an effort to ensure that the same bodies are examining the law compatibility of the administrative acts, or with any higher legal norm, administrative courts should be presented as a powerful instrument of guaranty of that review ${ }^{29}$.

\section{Conclusion}

Based on the reviews, studied in this paper, conclusions could be summarized in several key aspects:

Firstly, the process of reforming the judiciary under the new law on courts has brought improvement in the work

24 Ibidem, article, 18.

$25 \mathrm{Ibidem}$, article, 20.

${ }_{26}$ Personal interview with Mr. Krenar Berisha, a judge in the Basic Court in Pristina-department administrative issues, date April 2, 2013.

27 Ibidem

${ }^{28}$ The Chairperson of the Judicial Council Mr. Enver Peci, in a personal interview declared pro on the establishment of the Administrative Court.

${ }^{29}$ Esat Stavileci,"Gjyqësia administrative, mundësit dhe përparësitë", Paper presented at the scientific conference organized by the University "Marin Barleti" në Tiran, on 4.02. 2011 
and functioning of the judiciary. However, there were delays on the start of the work. The work on the review of the case, was supposed to start earlier and not having delays. The proof relays on the fact that the Department for Administrative Affairs of the Basic Court in Pristina has failed to decide on any case since January.

Secondly, the laws regulating administrative field in Kosovo, constitute a good foundation for the functioning of judiciary control of administrative work. But in this regard necessary changes should be made, particularly in the law on administrative procedure, as the current law allows the implementation of low on Administrative Procedure of Socialist Federal Republic of Yugoslavia, claiming that: "It replaces all of the provisions of the applicable law that are incompatible". As these two laws have the same scope, meanwhile the purpose of the new law is the development of completely new administrative procedure, reasonably the new law would have to completely replace the SFRY law. While not stating that supersedes the old law, the new law inevitably creates confusion, as both instruments remain effective, thus for each administrative issue, administrative authorities or court that addresses an administrative matter, need to determine which provisions of the old law are applicable.

Thirdly, the Republic of Kosovo needs to establish a special administrative court due to current conditions of the resolution of administrative issues. The small number of judges within the department on administrative issue at the Basic Court in Pristina, has no capacities to withstand.

Finally, the number of the judges in the Department on administrative issue should be increased as soon as possible. Available number of three judges, is considered too little to judge all those case that are already transferred from the Supreme Court, what leaves no space of consideration for new cases to come.

\section{References}

Esat Stavileci,"Hyrje në shkencat administrative" Prishtina, 1997;

Sokol Sadushi,"Kontrolli Kushtetues" Tirana, 2004;

Sokol Sadushi,"E drejta Administrative"Tirana, 2008;

Esat Stavileci,"Gjyqësia administrative, mundësit dhe përparësitë", Paper presented at the scientific conference organized by the University "Marin Barleti" në Tiran, on 4.02. 2011

Ina Puravelli dhe Julejda Gërxhi, "Domosdoshmëria e krijimit të gjykatës administrative bazuar në gjendjen aktuale të zgjidhjes së mosmarrëveshjeve administrative", Albanian Journal of Legal Studies, Volume 2, 2011;

The Constitution of the Republic of Kosovo, June 15, 2008;

European Convention on the Protection of Human Rights and Fundamental Freedoms and its Protocols;

UNMIK Regulation No. 2001/9, on May 15, 2001, on the Constitutional Framework for Provisional Self-Government in Kosovo as amended by UNMIK Regulation No. 2002 UNIMK / 9.03 in May 2002;

Law No. 03 / L-199 on the Courts August 24, 2010;

Law no. 02 / L-28 on Administrative Procedure, July 22, 2005;

Law Nr. 03 / L-202 on Administrative Conflicts, September 16, 2010;

Law on Regular Courts, Official Newspaper of SFRJ, no. 21, April 28, 1978;

Organization for Security and Cooperation in Europe (OSCE) -Mission in Kosovo, " First report on the Administrative Justice System in Kosovo ", April 2007;

Constitutional Court of the Republic of Kosovo, Annual Report, 2011;

The Supreme Court of the Republic of Kosovo, Work Report for 2012;

The Ombudsman of the Republic of Kosovo, Annual Report, 20 